\title{
Labor Market Conditions and Partisan Voting: How Unemployment Hurts the Left
}

\section{Anton Brännlund ${ }^{1}$ (1)}

Accepted: 26 October 2020 / Published online: 11 November 2020

(C) The Author(s) 2020

\begin{abstract}
Fluctuations in the labor market are a natural part of the business cycle, and they have attracted attention from political scientists for decades. Some scholars argue that left-wing parties benefit from rising rates of unemployment while others claim that voters rally behind conservative parties when the labor market weakens. I argue that the heterogeneous response of voters to a rise in the unemployment rate is due to differences in asset wealth. Put simply, the well-off have less need for social insurance, so they vote for conservative parties in order to put a cap on social spending when the unemployment rate rises; by contrast, asset-less voter opt for the left, with an eye to preserving their entitlements. I show with panel data from Swedish electoral districts that left-wing parties gain an electoral advantage when the local unemployment rate rises in less well-off areas, but they lose support when unemployment rises in wealthier districts.
\end{abstract}

Keywords Partisanship · Unemployment · Wealth · Social insurance

\section{Introduction}

Political scientists believe that changes in the unemployment rate have the power to influence democratic elections. It is furthermore commonly claimed, in both public and academic debate, that voters react to economic uncertainty. Unemployment should, therefore, generate electoral volatility, by impelling larger numbers of voters to worry about their economic safety or that of others. Some scholars accordingly argue that the economy is a partisan issue, in the sense that voters move along the left/right dimension as labor-market conditions change. Some argue that left-wing parties benefit from rising rates of unemployment because voters demand more government spending when economic conditions are harsh (Dassonneville and LewisBeck 2013; Wright 2012). Others contend that voters rally behind conservative

Anton Brännlund

anton.brannlund@statsvet.uu.se

1 Uppsala University, Gamla Torget 6, Uppsala, Sweden 
parties during economic downturns, as citizens who are about to tighten their belts prefer to cut down on government spending as well (Stevenson 2001; Durr 1993) and especially to tone down post-material policies associated with the left (Kayser and Grafström 2016).

Fluctuations in the labor market are a natural part of the business cycle, and they have attracted attention from political scientists for decades. One area within the overlap between politics and economics, however, has been less studied: the electoral consequences of the massive increase in household wealth. Due to rising asset prices, asset-owners have become significantly wealthier over recent decades, widening the gap between haves and have-nots. Wealth in the world has doubled since the year 2000 , and it is currently at $\$ 56,540$ per adult. Rising asset prices benefit households that hold assets, allowing them to become less dependent on government assistance during times of financial constraint. From this perspective, access to wealth can be said to reduce the economic insecurity workers experience when conditions on the labor market worsen-a mitigating effect that may spill over to their voting decisions as well. Hence, I ask: is the relationship between unemployment and voting decisions conditional on voters' wealth?

In contrast to researchers who make the frequent claim that pocketbook evaluations matter less for the economic vote (Lewis-Beck and Paldam 2000; Kiewiet and Lewis-Beck 2011), I argue that voters financial resources moderate the relationship between their voting patterns and broader economic conditions (like local unemployment levels). I proceed on the assumption that voters sort themselves on the left/ right axis based on their asset possessions, as studies now link asset wealth to support for conservative parties (Lewis-Beck et al. 2013; Foucault et al. 2013; Persson and Martinsson 2018). However, well-off voters do not necessarily oppose all types of government spending. They may simply have different preferences on what government funds should be spent on, given that they are less dependent on social security (Ansell 2014). Furthermore, there is reason to believe that the conflict between haves and have-nots intensifies when the unemployment rate rises, given that the costs of the social insurance system increase when the labor market weakens.

Put simply, well-off voters have less need for social insurance than their less favored counterparts do, so they may vote for conservative parties in order to keep a lid on social-insurance expenses when unemployment rises. Voters with few or no assets, on the other hand, opt for the left in order to preserve or expand their entitlements. This study represents a first attempt to model and estimate this conditional relationship. Using panel data from Swedish electoral districts, I show that groups of voters respond to unemployment in a heterogeneous manner, in that left-wing parties gain an electoral advantage when unemployment rises in less well-off areas. However, they lose support when unemployment rises in wealthier districts.

\section{Literature Review and Hypothesis}

The main findings from decades of research on the economic vote, mostly based on correlations between economic perceptions and expressions of support for the sitting government, can be summarized as follows: (1) Voters opt for the government 
during economic expansions, but support the opposition during contractions. (2) Voters engage in retrospective evaluation, meaning that they set more store by past economic performance than by future expectations. Furthermore, (3) voters are sociotropic, meaning that they put more emphasis on macro indicators than on their circumstances (Lewis-Beck and Paldam 2000; Kiewiet and Lewis-Beck 2011). However, the so-called reward/punish hypothesis has come in for criticism, as numerous studies have established that partisanship and past voting choices also shape economic perceptions (Gerber and Huber 2010; Ramirez and Erickson 2013; Bartels 2002; Ladner and Wlezien 2007; Enns et al. 2012; Johnston et al. 2005). This result calls into question the validity of earlier findings.

Other scholars argue instead that voters treat unemployment as a policy issue, in that they sort themselves on the left/right dimension following changes in labormarket conditions. For instance, Wright (2012) notes that unemployment in the US has historically been lower under Democratic incumbents and that voters in that country perceive Democratic administrations as better suited to handling economic slowdowns. He further shows, using data at the county level, that Democratic candidates gain an electoral advantage when the unemployment rate rises. Dassonneville and Lewis-Beck (2013) test this hypothesis further, using cross-country data from Europe: they find that higher unemployment increases the voting share for left-wing parties in opposition, but that its effects approach zero when the left comes to exercise greater control over the government. In other words, these scholars argue that voters can dislike unemployment but turn to the left rather than against the government if they believe that fiscal stimulus generates jobs. Other scholars, citing crossnational correlations, maintain that left-wing governments are penalized particularly severely for unemployment (Powell and Whitten 1993; Whitten and Palmer 1999).

Much evidence, furthermore, speaks against an unemployment-induced turn to the left, since some voters become less likely to support government spending during recessions, given that they must cut down on their expenses at such times. Durr (1993); Neve (2014), using time-series data from the US for the 1920-2008 period, find that voter sentiments grow more conservative as the economic outlook worsens. Stevenson (2001) finds additional support for this argument in a sample consisting of 14 Western democracies from 1956 to 1989. Markussen (2008) shows that this relationship only holds up to the late 1980s and becomes reversed in later periods (a pattern which naturally raises questions about causal interpretation). Still, Kayser (2009) finds that support for the left grows when the economy is stable even in periods after the 1980s and that right-wing governments are less likely to be punished for economic slowdowns (Kayser and Grafström 2016). Finally, Lindgren and Vernby (2016) illustrate with panel data from Sweden that the right-wing government gained support as a result of unemployment induced by the 2008 financial crisis.

These earlier studies, taken together, indicate that unemployment does not necessarily produce any particular pattern in voting. The possibility remains, however, that unemployment results in heterogeneous outcomes because different voters are affected differently. The problem is that most studies investigate micro and macro mechanisms simultaneously, basing their estimates both on the reaction of persons who are themselves unemployed and on the reaction of voters who are responding 
to a higher unemployment rate in general. Furthermore, unemployment not only inhibits economic growth; it also increases the level of economic insecurity among workers-i.e., the anxiety produced by a lack of economic safety (Osberg 1998). This anxiety is not necessarily limited to the unemployed; it can spread as well to employed workers if they come to fear losing their job in the future as unemployment rises.

A system of social insurance, however, enables workers to spread the risks they face in the labor market over time. Some scholars, accordingly, explain the strong support for the welfare state across a large part of the income-distribution curve in terms of popular support for inter-temporal rather than interpersonal transfers (Rehm 2012; Cusack et al. 2006; Iversen and Soskice 2001; Moene and Wallerstein 2001). Through the various benefits it offers, in other words, social insurance allows workers to maintain consumption levels during periods of income loss, as well as enabling them to search longer for a job matching their particular level of skill when they are unemployed (Chetty 2008). As a consequence, some scholars assert that the support for comprehensive social insurance is strong among workers who believe they will have a hard time finding another well-paid job (Iversen and Soskice 2001), as well as among workers who have either lost their job or confront general labormarket insecurity (Rehm 2009, 2011; Margalit 2013).

Asset-based welfare, on the other hand, is based on the principle that, rather than relying on social transfers from the welfare system, individuals should take greater responsibility for their own welfare by investing in assets (Doling and Ronald 2010; Ronald et al. 2017). Furthermore, Ansell (2014) shows that asset-owners become less likely to support social spending as the returns on their assets increase. He calls this the nest-egg effect: asset-owners use their possessions as a financial buffer during times of financial constraint. According to this argument, asset-owners will demand less in the way of public pensions and unemployment benefits as they grow wealthier because they can substitute their asset wealth for these goods.

However, this does not necessarily make asset-owners into fiscal conservatives in general (in the sense of demanding a smaller government overall). Instead, asset owners and the asset-less may simply have different preferences on what the government should spend money on, with the former favoring interest-rate deductions and subsidies on specific services, and the latter preferring social spending. This calculation makes asset returns to an interesting variable to study in this context, as suggested by Lindvall et al. (2013). These authors assert, by comparing the answers from the Swedish National Election Studies, that high-income voters are far more likely to perceive the economy as weak when asset prices fall. Economic recessions and recessions combined with financial panics should then be treated as separate types of events.

Further, the economy can have a heterogeneous impact on political competition, given that different groups exhibit different degrees of ability to cope with economic downturns. Lindvall (2017), for instance, illustrates with a sample covering 140 years of elections from 27 democracies that short economic downturns tend to benefit conservative parties. This effect arises since short term downturns only affect small groups of voters while leaving the middle class unaffected. The middle class becomes more fearful of higher taxation under these conditions and becomes more 
likely to vote for the right. However, long and deep economic downturns can, on the other hand, generate an advantage for the parties to the left.

In the Appendix, I demonstrate formally that two workers with different ability to cope with unemployment, in that they have differing asset returns have different reasons to react as the labor market weakens, given their differing dependence on social insurance. I further illustrate how the well-off demand less social insurance as the unemployment rate rises, given that wealth can be used as a substitute for social insurance in times of financial constraint. These results presume self-interested voters, contradicting the sociotropic-voting hypothesis. Experiments show, however, that self-interest plays a larger role in the decision-making process when actors have a clear stake and are primed to conduct a cost-benefit analysis of policy changes (Chong et al. 2001).

In other words, well-off citizens ought to perceive runaway social-insurance expenses as a threat to their interests, while people without assets should fear economic insecurity as unemployment rises. Thus, I show that unemployment will generate a tug-of-war over social spending between haves and have-nots, as a weak labor market reduces tax revenues at the same time that social expenditures increase. Moreover, social spending is often cut during recessions (Knotz 2018). According to some scholars, moreover, retrenchment in class-based social expenditures such as unemployment benefits follows a partisan pattern, in that right-wing governments make deeper cuts (Bandau 2017).

Asset-less voters, then, should vote for parties to the left on the political spectrum when the unemployment rate rises, given that they wish to preserve or expand their entitlements. Voters with higher returns on their assets, on the other hand, should become more supportive of parties of the right under such conditions, as they want to keep a lid on social insurance expenditures. Hence, I hypothesize, that parties to the left will gain an electoral advantage in areas where voters have comparatively fewer assets, and that parties to the right will gain an advantage in areas where voters are well-off.

This hypothesis relates to studies that suggest that different groups in the electorate can react to changes in the macroeconomy based on their self-interest and views on government spending rather than sociotropic evaluations (Lindvall 2017; Kayser and Grafström 2016). I contribute to this literature with the current paper in that I theorize about and investigates the self-interest mechanism more directly.

\section{Political Conflict}

My sample covers four elections between 2002 and 2014. This period saw a mixture of cabinets, with the Social Democrats governing between 2002 and 2006, and a Conservative/Liberal government ruling between 2006 and 2014. There was also a apparent left/right conflict in Swedish politics during this period, as much of the political debate centered on reforms to the social-insurance system.

Sweden has institutions in place that regulate both the incidence of risk on the labor market and the risk of requiring unemployment benefits. First, employed workers in Sweden are protected by labor-market rules that strictly regulate the 
dismissal of employees. The Employment Protection Act, which was adopted in 1982, forces employers to follow strict procedures when terminating employment. It specifies minimum notice times, terms of priority, and permissible reasons for termination. Employers must lay off staff in accordance with seniority, whereby the last worker hired is the first to be let go. This greatly reduces the risk of unemployment for labor-market insiders. All Swedes, furthermore, are entitled to basic economic security in case of unemployment, illness, or old age provided through the social-insurance system. These entitlements are financed through taxation and social security contributions, and they account both for a major share of the budget and for a large proportion of GDP.

After the election of 2006, the new Conservative/Liberal government introduced a policy aimed at reducing unemployment and freeing up government funds. Important changes included a significant reduction in income taxes, an increase in the coverage fee for unemployment benefits, and reduced access to long-term sick-leave benefits. These reforms were heavily criticized by the leftwing parties and the labor unions, and they remained a salient issue for many voters in later elections. Based on these conditions, I argue that Sweden during the 2002-2014 period serves as an ideal testing ground for my hypothesis, given that voters likely sorted themselves on the left/right dimension based on where they stood on these social-insurance reforms.

The dependent variable in this study is changes in the electoral advantage for the left (LWA) in each electoral district $d$, defined as follows:

$$
\begin{aligned}
\Delta L W A_{d t}= & \left(\text { Vote share left bloc }{ }_{d t}-\text { Vote share right bloc }{ }_{d t}\right) \\
& -\left(\text { Vote share left bloc } c_{d t-1}-\text { Vote share right bloc } c_{d t-1}\right)
\end{aligned}
$$

I register a vote for the right-wing coalition when an individual votes for the Moderate Party, the Liberal Party, the Center Party, or the Christian Democrats. I register a left-wing vote when a person opts for the Social Democratic Party, the Left Party, or the Green Party. The left-wing advantage is simply the difference between these blocs. The reason for analyzing the left-wing advantage rather than the rightwing one is that I expect the left-wing parties to advance as a consequence of rising unemployment, everything else being equal. However, this advantage should diminish with increasing asset returns.

In my analysis, I use data from electoral districts which have been provided by Statistics Sweden (SCB). Electoral districts in Sweden are small areas nested within larger municipalities, usually with some 1000-2000 eligible voters. The number of voters in my sample ranges from 121 to 2809 in each district. However, the number of districts varies between elections, and I keep only those who remain throughout the entire period. After erasing temporary districts and those that disappear in later elections, I end up with a total of 4475 districts, which can be compared with the 5668 districts registered in the 2014 election. The main purpose of erasing temporary districts is to make it possible to control for individual trends in voting over time. Summary statistics for key variables and district characteristics can be found in the Appendix. 


\section{Unemployment}

How much do subjective macro-economic evaluations rather than actual economic outcomes affect voter choice? This is a central question in the literature on economic voting. The issue arises because there are methodological problems associated with using real macro-economic indicators in empirical work. One problem is that objective national conditions only vary between elections-not between voters. Another issue is that a design which makes use of objective national conditions loses the ability to control for election-specific effects, which-given the risk of spurious correlations - can be troublesome. Using subjective evaluations of the economy solves these two issues, but at the same time, it opens for reversed causality, because perceptions may reflect partisanship.

Hansford and Gomez (2015) solve this issue by using changes in the local unemployment rate as an instrumental variable for individual perceptions of social conditions. The intuition behind this strategy is simple: voters living in areas with high unemployment will tend to believe the general unemployment rate is higher than will voters living in areas with low unemployment. The link between the local economic context and voting patterns is well-documented (Simonovits et al. 2018; Park and Reeves 2018; Reeves and Gimpel 2012; Elinder 2010; Ansolabehere et al. 2014; Hansford and Gomez 2015; Simonovits et al. 2018). Nevertheless, how local is local enough for voters? How small should the areas of interest be?

With data from Denmark, Bisgaard et al. (2016) show that the unemployment rate in the immediate neighborhood significantly predicts perceptions of the national economy, and that it influences voter choice as well. Anderson and Roy (2011) demonstrate that neighborhood-level information is an important cue for national economic conditions, but that this relationship weakens as voters become better informed and educated. These results suggest that voters can form economic perceptions on the basis of conditions in quite small areas, such as electoral districts. These districts lie somewhere between the neighborhood and municipal levels, as they contain different neighborhoods but are nested within municipalities. The data I have obtained come from Statistics Sweden, and I define my independent variable as follows:

$$
N E \text { growth }_{d t}=\frac{N E_{d t}-N E_{d t-1}}{N E_{d t-1}}
$$

where $N E$ is the share of non-employed individuals over 15 years old. Using relative changes rather than absolute changes can provide an advantage in that they should be more independent of historical area information. That is to say, voters are more likely to notice swings in the non-employment rate that are large in their particular context.

An important note here, on the other hand, is that non-employment is not the same as unemployment but will, as I make use of register data, serve as the best operationalization. Registered data on actual unemployment is in contrast to the non-employment rate based on the number of people registered at the unemployment office. This data, in turn, makes the unemployment rate endogenous to political decisions. During 
the period studied in this paper, many reforms were implemented, which changed the incentive to register as unemployed. To not confuse such institutional changes with actual changes in the unemployment risk, I prefer a measure based on non-employment (the share of people without a job).

Figure 1 provides information on the distribution of non-employment growth across the districts. The histogram has been trimmed to allow for easier interpretation, in that I leave out extreme values at the right and left tail-end. Two events drive much of the variation in non-employment between the districts. First, the IT sector took a heavy hit in the aftermath of the dot-com bubble, but the layoffs were fairly contained. This situation means that districts (often in or around Stockholm) where a large share of voters were employed in the IT-sector were heavily affected during this period. Second, the financial crisis of 2008 affected many export industries in the country's southwestern areas, but left Stockholm mostly unharmed.

\section{Net Asset Returns per Eligible Voter}

Due to a lack of data, I use a proxy variable for asset-wealth returns in the electoral districts over time. This proxy consists of returns in assets (changes in asset value), and debt payments. Consider Specification (3):

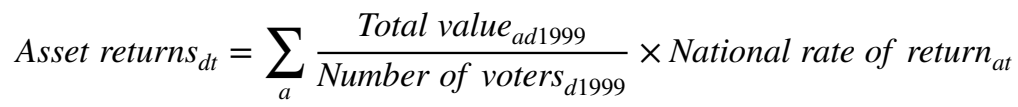

Asset returns $_{i t}$ are defined as the total value of asset class $a$ in district $d$ during the year 1999 (please see the Appendix for the initial wealth distribution), divided by eligible voters (citizens over 18 years old) in the district in that period, multiplied by the national rate of return in asset class $a$ in period $t$, where $t=(2006,2010,2014)$.

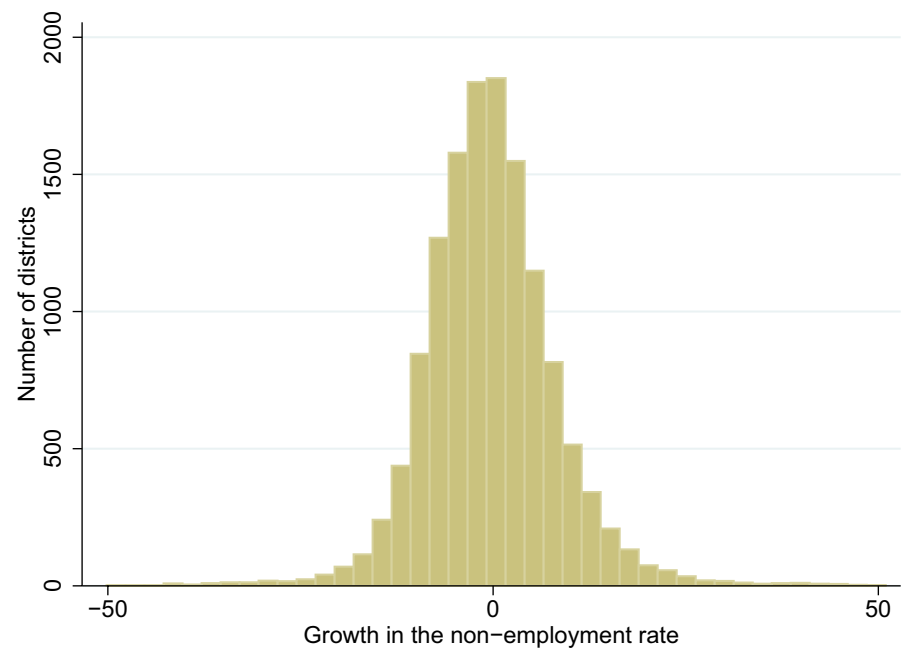

Fig. 1 Distribution of growth in non-employment in percent 
Here $a=$ (houses, apartments, or mutualfunds) and I combine bond funds and mixed mutual funds to create the category called mutual funds. Data has been provided by Statistics Sweden (SCB), and the total value of each asset class has been generated from the Swedish Wealth Register. This register, is in turn, based on data from tax collection and is only available for the period 1999 to 2006 as the wealth tax was abolished in 2007. SCB has aggregated the total value of each asset class in these geographical areas in the available years, and I simply merge the wealth data with data on the populations of the districts in order to calculate the initial value per asset class and voter during the base year 1999.

The national rate of return is simply how much the total stock of asset class $a$ has grown in percentages between elections. By multiplying these trends in national returns with their associated level of asset wealth per voter in the district, I receive a proxy for asset returns over time. Put simply: Actual asset returns will increase more rapidly in districts where voters own more of asset class $a$ when the return from this asset class increases in Sweden. Correspondingly, asset returns will decrease faster in these districts when the value of that asset class decreases.

Let us now consider debt payments as these should greatly matter for households in this context in that high debt payments will deplete any wealth surplus :

$$
\text { Debt payments }_{d t}=\frac{\text { Total debt }_{d 1999}}{\text { Number of voters }} \text { vi1999 }_{\text {Average interest rate }} \times 4
$$

Debt payments ${ }_{d t}$, on the other hand, are defined as the total value of household debt in district $d$ during the year 1999, divided by eligible voters (citizens over 18 years old) in the district in that period, multiplied by the average interest rate in period $t$ times four (since households have to make four debt payments between the elections). As before, I connect the total value of debts from the Swedish Wealth Register to population size in order to get the initial debt per eligible voter. The equation simply states that heavily indebted districts will be drained on funds during times of high-interest rates. Thus, I define my wealth proxy Net asset returns ${ }_{d t}$ as specified in Eq. (5):

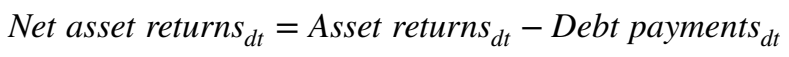

Housing has been the main driver behind most asset returns, for the average home has doubled in value during this period. Housing wealth is by far the most common form of wealth, given that most Swedish households are homeowners. Some inner-city districts have zero wealth in housing, as their residents live in apartment cooperatives; this, however, makes apartment wealth a less evenly distributed asset class. Households can realise real-estate equity through loans, making it possible for them to spread consumption out over a lifetime. A widespread resort to such loans has made Swedish households heavily indebted. Households in Sweden are among the most heavily indebted in the world, which makes them sensitive to changes in interest rates and asset valuations.

I exclude stocks from the Net asset returns ${ }_{d t}$, because a proxy based on this asset class bears no significant relationship to changes in stock-based wealth per voter at the district level. This is perhaps to be expected if a small group controls 
a majority of stock wealth and since individual stocks can deviate from the average growth rate in the stock market. This situation can become problematic if business-owners own a large share of their own companies. Still, even if the distribution of financial wealth is highly skewed, a majority of Swedes do save in mutual funds.

The net asset returns are expressed in real terms and are a measure of actual changes in district net wealth. As I show in the Appendix, the Net asset returns $s_{d t}$ variable does a good job of predicting actual asset returns during the years for which data are available: i.e., 1999 to 2006. An increase of 1 SEK (Swedish Krona) in Net asset returns at $_{\text {is }}$ associated with an increase of approximately 0.6 SEK in total net wealth per voter, where net wealth per voter refers to the value of all assets minus the total cost of assets divided by the number of eligible voters.

Moreover, volatility in both real and financial asset valuations is evident in the data, as the rebound after the dot-com bubble and the global financial crisis took place within this period. Figure 2 shows the net asset returns between 2002 and 2014. The histogram has been trimmed to allow for easier interpretation, in that I leave out extreme values at the right tail-end. We can find positive asset returns as large as 2,000,000 SEK, but the average return is only 80, $000 \mathrm{SEK}$, and the standard deviation is 1.2 .

\section{Main Specification}

The relationship of interest in this study is described in Eq. (6), the average impact from relative growth in non-employment on changes in the left-wing advantage, conditional on changes in net wealth i.e., net asset returns:

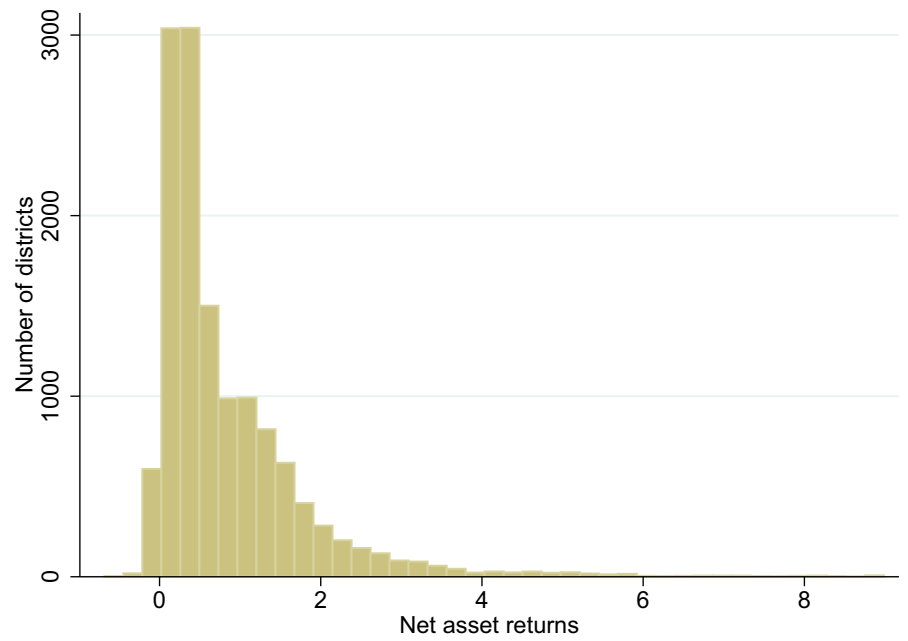

Fig. 2 Net asset returns expressed as hundred thousands of SEK 


$$
\begin{aligned}
\Delta L W A_{d t}= & \beta_{1} \times N E \text { growth }_{d t}+\beta_{2} \times \text { Net asset returns } \\
& +\beta_{3} \times N E \text { growth }_{d t} \times \text { Net asset returns } \\
& +\beta_{4} \times \Delta X_{d t}^{\prime}+\beta_{5} \times \Delta X_{d t}^{\prime} \times \text { Net asset returns } \\
d t & +\psi_{d}+\zeta_{t m}+\varepsilon_{d t} .
\end{aligned}
$$

Here, the dependent variable is the left-wing advantage (expressed in changes to get rid of unobserved heterogeneity) at the electoral district level $d$ in period $t$ where $t$ goes from 2006 to 2014. The sign and significance of the interaction term $\left(\beta_{3} \times N E\right.$ growth $_{d t} \times$ Net asset returns $\left.{ }_{d t}\right)$ will tell us whether there is an interaction effect between relative changes, or growth in non-employment and changes in net asset returns.

One potential issue is that changes in local non-employment rates reflect an equilibrium between both supply and demand factors, where the supply is determined by demographic characteristics. These characteristics will most likely determine partisanship and economic perceptions. A big potential problem is that some districts can attract groups of voters with certain characteristics over time which cause fluctuations in the left-wing advantage. A direct way of controlling for this is to add a vector with control variables $X$. In this setup, it will be necessary to control for changes in the demographic structure and educational levels, since changes in these variables will determine both labor supply and voting choice.

I include the following variables in $X$ : average age, age squared, the average level of education, and the share of the population consisting of migrants. These variables will also correlate with the number of people employed, with economic perceptions, and with voting choices. However, by including only the vector $X$, I control for the linear effects of these covariates. Nevertheless, it is possible that they still confound the interaction term between growth in the non-employment rate and the Net asset returns . . To solve this problem, I also enable vector $X$ to interact with my wealth proxy.

A remaining concern is all the possible unobserved characteristics. To handle them, I include a district-specific fixed effect $\psi_{d}$. This fixed effect will not only control for linear trends in voting and the initial distribution of wealth. It will also, at the same time, purge the estimates from all confounders that constantly grow within the districts over time. Finally, the last concern is election-specific events that affect all districts in the same way. To make sure I am comparing similar districts, I include municipality by year fixed effects $\zeta_{m t}$ where $m$ goes from 1 to 290. In doing so, I allow for heterogeneous election effects across different municipalities. This approach allows me to cancel out both the local economic and political contexts, as the identifying variation now comes from a comparison between districts within a given municipality and period.

\section{Results}

Table 1 presents the conditional and unconditional effect of non-employment on the left-wing advantage. Column 1 shows the bivariate relationship between the share of non-employed workers and the left-wing advantage in levels. It can be interesting to see 
Table 1 Non-employment, asset returns and the left-wing advantage

\begin{tabular}{|c|c|c|c|c|}
\hline & 1 & 2 & 3 & 4 \\
\hline Share of workers not employed & $\begin{array}{l}1.417 * * * \\
(0.0383)\end{array}$ & & & \\
\hline Non-employment growth & & $\begin{array}{l}0.301 * * * \\
(0.0244)\end{array}$ & $\begin{array}{l}0.0755 * * * \\
(0.0182)\end{array}$ & $\begin{array}{l}0.151 * * * \\
(0.0233)\end{array}$ \\
\hline Net asset returns & & & & $\begin{array}{l}-0.507 * * * \\
(0.210)\end{array}$ \\
\hline Non-employment growth $\times$ net asset returns & & & & $\begin{array}{l}-0.0833 \text { *** } \\
(0.0136)\end{array}$ \\
\hline Constant & $\begin{array}{l}-53.56^{* * * *} \\
(1.549)\end{array}$ & $\begin{array}{l}-1.092 * * * \\
(0.00484)\end{array}$ & $\begin{array}{l}2.443 * * * \\
(0.262)\end{array}$ & $\begin{array}{l}3.005 * * * \\
(0.353)\end{array}$ \\
\hline $\mathrm{N}$ & 17896 & 13413 & 13413 & 13392 \\
\hline Year by municipality effects & No & Yes & Yes & Yes \\
\hline Controls & No & No & Yes & Yes \\
\hline Controls interacted with net asset returns & No & No & No & Yes \\
\hline Districts effects & No & No & No & Yes \\
\hline
\end{tabular}

Standard errors clustered at the district level in parentheses

$* p<.10, * * p<.05, * * * p<.01$

how this relationship looks like as it serves as a naïve contrast to the full specification presented in column 4. Further, this test will reveal if the left-wing parties dominate in economically vulnerable areas. This coefficient is large and quite strong, indicating that the advantage for the left increases by almost $1.5 \%$ points when the non-employment rate increases by $1 \%$ point on average. Non-employment seems, in other words, to be an excellent predictor for the left-wing advantage in Sweden; however, this is not to say that non-employment produces this outcome. Column 2 presents the results of a regression where I regress changes in left-wing bloc advantage on relative changes in nonemployment rates. This estimate is much smaller (0.3), which indicates that a $1 \%$ rise in non-employment rates increases the electoral advantage by $0.3 \%$ points.

In column 3, I present the effect of relative changes in non-employment on voting conditional on all remaining time-variant confounders. Adding these controls reduce the estimate to 0.08 , which is quite different from the more naïve results presented in column 1. Furthermore, looking at column 4, where I enable relative changes in nonemployment rates to interact with asset returns, we find a significant interaction effect in the expected direction. In essence, the marginal effect of growth in non-employment on the advantage for the left diminishes with increasing net asset returns.

I plot the conditional effect of relative increases in non-employment in Fig. 3, together with a histogram of the distribution of the net asset returns. This approach allows us to see how the conditional effect of non-employment (Y-axis) fluctuates with increases in net returns (X-axis). This histogram can help us ascertain whether there are enough observations through the whole sample from which to estimate the conditional effects. The average net asset return in the sample was 0.8 , indicating that non-employment had a small positive impact on the left-wing advantage. 


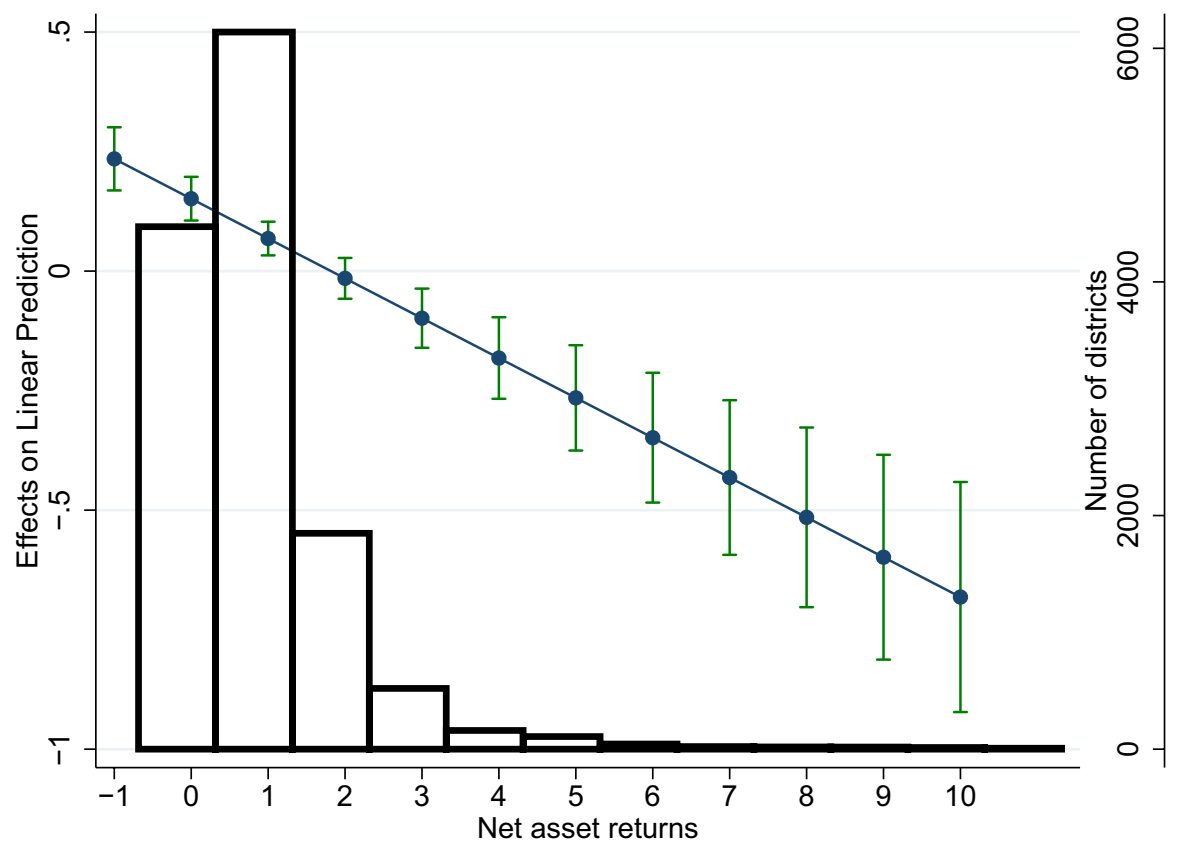

Fig. 3 The effect from growth in non-employment on changes in left-wing advantage conditional on net asset returns with $95 \%$ confidence level intervals. Net asset returns are expressed as hundreds of thousands of SEK

The downward sloping line indicates that the advantage for the left-wing bloc generated by non-employment growth diminishes in wealthier districts. However, really large negative effects are restricted to the right tail-end of the net asset return distribution, where we find fewer observations. Equally true, the left advantage seems to grow substantially as non-employment in asset-poor districts increases; however, the small number of observations at the left tail-end raises the question of whether we really can extrapolate the linear pattern through the whole sample. Still, the pattern found in Fig. 3 lends some partial support to the hypothesis but suggest at the same time that it is only in very wealthy districts that the left loses support from rising non-employment.

One can also break down these results further, by estimating the conditional impact of non-employment rates on each party in the left-wing bloc. These parties are the Social Democratic Party, the Green Party, and the Left Party. We find the same pattern in Fig. 4 for all of these parties, but the estimates vary in size and significance. The clearest conditional effect is found for the Social Democratic Party, the largest of the three parties and also the largest party in Sweden. This test confirms that the increase in left-wing advantage is driven by an increase in support for the left-wing bloc. I run a similar analysis on the right-wing parties in the Appendix, which confirms that all of these parties except the Liberals gain support from growth in non-employment as net asset returns increase. 


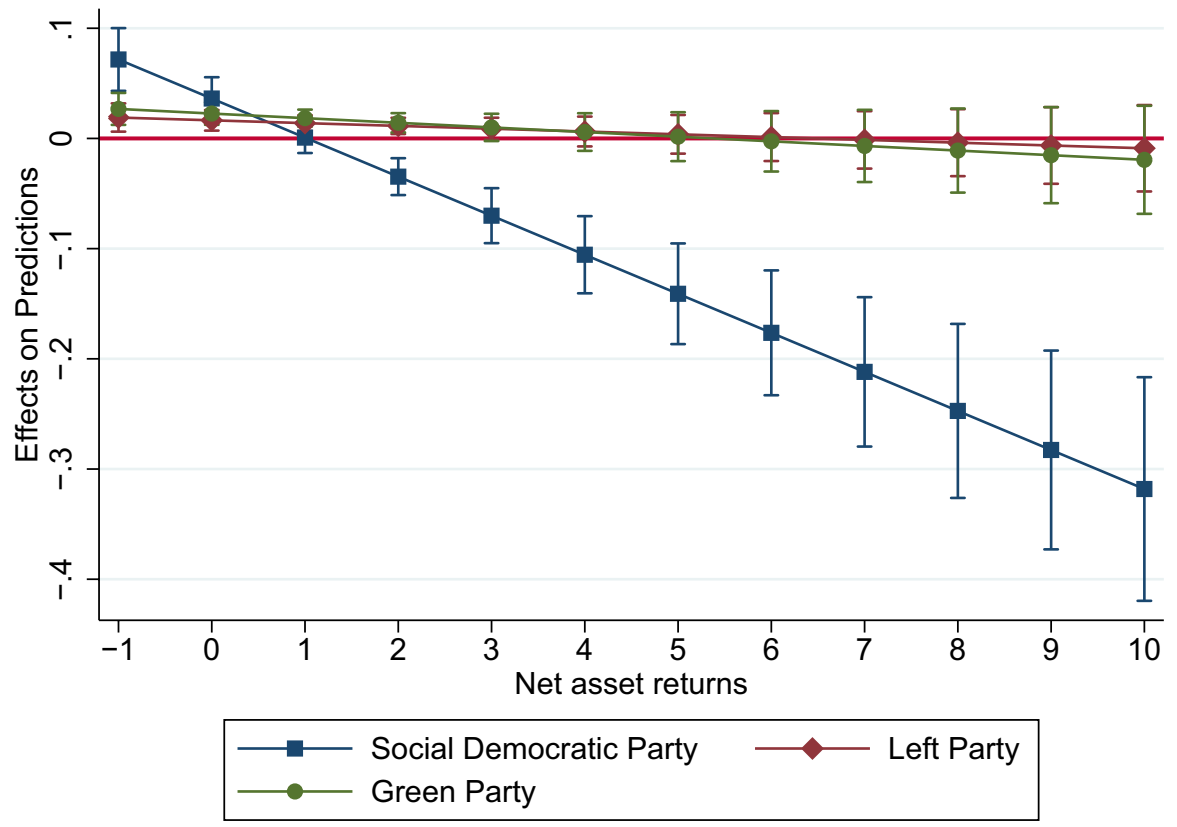

Fig. 4 The effect from growth in non-employment on changes in support for the individual left-wing parties conditional on net asset returns with $95 \%$ confidence level intervals. Net asset returns are expressed as hundred of thousands of SEK

\section{Robustness Checks}

There are some potential problems associated with the analysis in the main results that I will address further in this section and the results from these tests can be found in the Appendix. First, following Hainmueller et al. (2019), I estimate a bin model to investigate the functional form of this interaction in more detail in Appendix 5. As I model it in specification 6 , the effect of relative increases in non-employment is only allowed to change linearly with the net asset returns. This estimation requires a strong assumption that a one-unit increase in net asset returns changes the impact of nonemployment on the left-wing advantage with some parameter $\beta$, and that this effect is constant across all values of net returns. I, therefore, compare my results to a bin model, where the conditional marginal effects are free to vary. This approach produces a similar result: i.e., the left-wing advantage induced by non-employment diminishes in wealthier districts.

Furthermore, to rule out a reward-punish mechanism, I test the conditional effect on changes in vote share for the government parties. These results indicate that governments are in general less punished for unemployment in well-off areas on the one hand but also show that governments never benefit from a weaker labor market, independent of net asset returns (Appendix 6).

Another potential problem is the sample, given that I discard districts that do not remain throughout the whole period 2002-2014. To make sure that sample selection does not drive the main result, I runt two additional tests. In the first test, I run my main 
specification on a larger sample (See Appendix 7), and this result is not different. However, to toughen up this test even further, I also run a similar analysis at the municipality level between 1988 and 2014 (Appendix 8). The outcome of this exercise is very similar and illustrates that the result is not bound to this particular sample or period. If anything, this test suggests that the effect is stronger over the longer panel.

However, another concern is the presence of very influential elections with specific contexts, such as the 2010 election in the aftermath of the financial crisis. Overall, different drivers behind changes in the non-employment rate could generate different types of reactions among voters. I break down the result on separate elections to investigate this possibility in Appendix 9. This test suggests that the same pattern is found over time in that the size of the interaction term has not varied between individual elections. Still, it should be noted that the estimates obtained from these tests are very imprecise, but the same pattern is found in each separate election.

Moreover, an attentive reader might suggest that unemployment and non-employment rates are two separate phenomena, so I also show that relative changes in the unemployment rate produce a result that resembles the result produced by relative changes in the non-employment rate (Appendix 10).

One final concern is the ecological fallacy, or in other words, how do we know that it is the wealthy who react to changes in the unemployment rate? To investigate this, I introduce survey data to disentangle these effects in Appendix 11. The main idea is simple: I investigate if changes in net wealth moderate the relationship between labor market uncertainty, measured as occupational unemployment rates and left-wing voting. I found that changes in net wealth decrease the probability among those who are employed in insecure occupations to vote for a left-wing party. This evidence suggests that a similar mechanism could exist a the individual level.

\section{Discussion and Conclusion}

A growing number of studies indicate that conservative parties benefit during periods of economic hardship. The argument is that citizens who are about to tighten their own belt grow more skeptical of government spending. A smaller group of studies, on the other hand, finds that parties to the left on the political spectrum gain an electoral advantage during periods of high unemployment because citizens believe that an expansive fiscal policy is more likely to generate jobs. In this study, on the other hand, I expand on the ideas presented in Markussen (2008) and Ansell (2014): i.e., I argue that voters react because unemployment changes the level of demand for social insurance. I further show that the heterogeneous response of voters to a rise in the unemployment rate can be due to differences in asset wealth. Put simply, the well-off have less need for social insurance, so they vote for conservative parties in order to put a cap on social spending when the unemployment rate rises; by contrast, asset-less voters opt for the left, with an eye to preserving their entitlements.

However, my results indicate that the left loses support from a weak labor market only in very wealthy areas. Still, these results suggest that wealth can help to explain empirical inconsistencies in the literature on economic voting. More precisely, the results indicate that different types of recessions give rise to different electoral 
outcomes, because economic variables such as unemployment and income growth are often (although not always) correlated with asset returns. A recession accompanied by broad falls in asset prices and rising interest rates can spark an increase in support for the left, as asset-owning households are reminded of the risk of their investments. An independent slowdown on the labor market, on the other hand, may create an electoral advantage for conservative parties, if members of the asset-owning middle class come to fear higher social expenditures instead.

These results also contradict much of the earlier wisdom in the literature on economic voting, in that they confirm the occurrence of pocketbook behavior among voters. The standard hypothesis among scholars of economic voting in recent decades has been that voters evaluate policies on a sociotropic rather than a pocketbook basis. This study, on the other hand, suggests that voters react to changes in the macro economy for highly selfish reasons as previously suggested by Lindvall (2017); Kayser and Grafström (2016).

The argument in this paper is not on the other hand that wealthy unemployed voters are opting for right-wing parties. On the contrary, it could even be beneficial for them to free ride on the social insurance system if they knew that they would remain without a job for the foreseeable future. Instead, I recognize that most citizens face some employment uncertainty, and neither the employed nor the unemployed are certain about their future labor market status. However, the impact from labor market risks should decrease of wealth. Put simply: the well-of can have better use for programs such as interest rates deductions even as the economy is deteriorating and can therefore, refrain from supporting the left to protect similar programs from retrenchment. This would on the other hand not be in a state of certain unemployment.

Still, one limitation of the present study, however, is that I investigate micro and macro factors simultaneously: i.e., some of the voters are non-employed themselves, while others form their economic perceptions on the basis of the number of unemployed citizens in their district. In other words, the main analysis cannot tell which voters who abandon the left as they grow more wealthy, but some some additional tests suggest that similar patterns might hold at the individual level as well.

That said, future research can certainly go further in strengthening both internal and external validity. First, if possible, a more exogenous source of changes in unemployment should be used, in order to avoid the impact of compositional shocks in the population. Second, future research should strive to isolate the impact on individuals and actual social policy preferences rather than aggregated voting patterns.

Acknowledgements I am grateful for the helpful comments from Håkan Brännlund, Karl-Oskar Lindgren, Pär Nyman, Linuz Aggeborn and two anonymous reviewers. This study was partly financed by the Swedish Research Council, (Grant Nos. 2017-00764 and 2019-00244). Replication codes and data are available at the Political Behavior Dataverse or at the following address: https://doi.org/10.7910/DVN/ BA2WPD. All errors are my responsibility.

Funding Open access funding provided by Uppsala University. 


\section{Compliance with Ethical Standards}

Conflict of interest The authors declare that they have no conflict of interest.

Open Access This article is licensed under a Creative Commons Attribution 4.0 International License, which permits use, sharing, adaptation, distribution and reproduction in any medium or format, as long as you give appropriate credit to the original author(s) and the source, provide a link to the Creative Commons licence, and indicate if changes were made. The images or other third party material in this article are included in the article's Creative Commons licence, unless indicated otherwise in a credit line to the material. If material is not included in the article's Creative Commons licence and your intended use is not permitted by statutory regulation or exceeds the permitted use, you will need to obtain permission directly from the copyright holder. To view a copy of this licence, visit http://creativecommons.org/licen ses/by/4.0/.

\section{Appendix 1: Formal Model}

I start by setting up a one-period model of the demand for social insurance among voters. In this section, I lay out the conceptual framework and study the impact on the demand for social insurance after (1) a rise in the individual risk of unemployment, and (2) a rise in the general unemployment rate. More precisely, I formalize how the return from privately held assets reduces the demand for social insurance among voters when they face a higher risk themselves or observe a higher unemployment rate in society. This model is a modified version of the one presented in Markussen (2008); Ansell (2014). Here I study the simplest model possible of how wealth mitigates and moderates the relationship between unemployment and the demand for social insurance.

Setup I study the demand for social insurance made by individual citizens who operate in a world with two states of nature: a good state of nature (realized with the probability $p$ ) where citizens work, and a bad state of nature (realized with probability $(1-p)$ where citizens experience a negative income shock. The shock suffered by citizens in the latter may be due to old age, sickness, layoffs, etc. The critical thing is that citizens in the bad state of nature can no longer earn their livelihood on the labor market.

The individual budget constraint In the good state of nature, workers receive the net wage $w$, which equals $W(1-t)$ where $W$ is the gross wage and $t$ is the incometax rate. In this model, I assume for simplicity's sake that all workers receive the same wage, so that the wage for the individual worker equals the average wage $\bar{W}$. This is a reasonable assumption given that we are interested in the impact of a rise in the unemployment rate on policy preferences across the wealth rather than the income distribution. In the bad state of nature, workers receive the unemployment benefit $b$. However, in addition to both the benefit and labor income, workers have assets from which they receive the return $A$, of different size, which can be used to increase consumption in both the good and the bad state of nature.

Preferences and behavior Let $U(c)_{i}$ represent the individual utility as a function of consumption for the citizen in each state of nature. Furthermore, citizens in this model find themselves behind the veil of ignorance, in that they have to 
choose an optimal tax rate without knowing whether they will end up in the good state of nature or in the bad one. Instead, the good and the bad state of nature are two outcomes in a lottery with different probabilities. This is described more formally in the following utility function:

$$
U(c)_{i}=p u_{i}[\bar{W}(1-t)+A]+(1-p) u_{i}[b+A]
$$

Here workers receive their net income plus asset returns in the good state of nature, or the benefit plus asset returns in the bad state of nature, which is spent on consumption. I make use of the standard assumption:

$$
\begin{aligned}
U^{\prime}(c)_{i} & >0 \\
U^{\prime \prime}(c)_{i} & <0
\end{aligned}
$$

This means workers derive decreasing marginal utility from an increase in consumption, and that workers in the bad state of nature receive more utility from an increase in consumption than do workers in the good state of nature, everything else being equal. To obtain my results, I impose a more specific form on this utility function. More precisely, I follow Iversen and Soskice (2001) in imposing the assumptions of the Arrow-Pratts relative risk aversion $(R R A)$ utility function, where:

$$
\begin{array}{r}
u(c)=\frac{c^{(1-a)}}{1-a} \forall a>0, \neq 1 \\
\log c \text { for } a=1 .
\end{array}
$$

Here $a$ is the coefficient of relative risk aversion, and workers will avoid risk to a greater extent when $a$ grows larger. Furthermore, the individual citizen in this model consumes all disposable income in each state of nature, meaning that no savings decisions are involved. Formally, the individual citizen in each state of nature solves the following problem:

$$
\max U(c)_{i} \text { s.t. } c=w+b+A
$$

The government budget constraint The government finances the benefit $b$ through income taxation, and the benefit is and remains the only component in the government's budget. This budget then becomes:

$$
\tau(t) \bar{p} \bar{W}=(1-\bar{p}) b
$$

which implies that:

$$
b=\frac{\bar{p}}{1-\bar{p}} \tau(t) \bar{W}
$$

Here the total workforce is normalised to one, $\bar{p}$ represents the average employment rate, $\tau(t)$ a tax function. This function follows the assumption of the Laffer curve, in that the incentive for businesses to operate approaches zero as that tax rate 
approaches $100 \%$. This means that $\tau \prime(t)>0, \tau \prime \prime(t)<0$ and that the policy-maker faces a tax ceiling above which higher taxes only reduce revenues.

Individual risks, asset returns, and the demand for social insurance We can substitute $b$, in the utility function of the worker, with the government budget constraint. This leaves us with the following equation:

$$
U(c)_{i}=\frac{p}{1-a} u_{i}((1-t) \bar{W}+A)^{(1-a)}+\frac{(1-p)}{(1-a)} u_{i}\left(\frac{\bar{p}}{1-\bar{p}} \tau(t) \bar{W}+A\right)^{(1-a)}
$$

Now we can start to investigate how voters behave when the unemployment rate fluctuates. The first step is simply to find the expression for the optimal tax rate, which we do by maximizing the utility function with respect to $t$ :

$$
\frac{\partial U(c)_{i}}{\partial t}=-p \bar{W}((1-t) \bar{W}+A)^{-a}+(1-p)\left(\frac{\bar{p}}{1-\bar{p}} \tau(t) \bar{W}+A\right)^{-a} \frac{\bar{W} \bar{p}}{1-\bar{p}} \frac{\partial \tau(t)}{\partial t}=0 \equiv g
$$

The negative part of this equation represents the marginal cost and the positive part the marginal benefit from a tax increase for the individual citizen. A worker with completely secure employment $p=1$ will thus pay a high price for an increase in the tax rate. However, workers with less secure jobs can use the tax rate or asset returns to smooth consumption across periods of employment and unemployment. Workers who face certain unemployment $p=0$ have much to gain from a tax increase, since they have no taxable incomes. Let us call this function $g$.

To see how a change in the individual risk of unemployment affects the demand for social insurance, we first assume that all workers face the same labor-market risks, so that $p=\bar{p}$. Second, we use the following relationship in order to find out how the demand for social insurance changes as the unemployment rate fluctuates:

$$
\frac{\partial g}{\partial t} \Delta t+\frac{\partial g}{\partial \bar{p}} \Delta \bar{p}=0 \Rightarrow \frac{\partial g}{\partial t} \Delta t=-\frac{\partial g}{\partial \bar{p}} \Delta \bar{p} \Rightarrow \frac{\Delta t}{\Delta \bar{p}}=-\frac{\partial g / \partial \bar{p}}{\partial g / \partial t}
$$

Note however that $\partial g / \partial t<0$ given that $\frac{\partial^{2} \tau(t)}{\partial t^{2}}<0$ :

$$
\begin{aligned}
\frac{\partial g}{\partial t} & =-a p \bar{W}^{2}((1-t) \bar{W}+A)^{-(1+a)} \\
& -a(1-p)\left(\frac{\bar{p}}{1-\bar{p}} \tau(t) \bar{W}+A\right)^{-(1+a)}\left(\frac{\bar{W} \bar{p}}{1-\bar{p}} \frac{\partial \tau(t)}{\partial t}\right)^{2} \\
& +\frac{\partial^{2} \tau(t)}{\partial t^{2}} \frac{\bar{W} \bar{p}}{1-\bar{p}}(1-p)\left(\frac{\bar{p}}{1-\bar{p}} \tau(t) \bar{W}+A\right)^{-a}
\end{aligned}
$$

In other words, we are mainly interested in the sign of $\partial g / \partial \bar{p}$ : 


$$
\begin{aligned}
\frac{\partial g}{\partial \bar{p}} & =\bar{W}((1-t) \bar{W}+A)^{-a}+\bar{W} \frac{\partial \tau(t)}{\partial t}\left(\frac{\bar{p}}{1-\bar{p}} \tau(t) \bar{W}+A\right)^{-a} \\
& -a \frac{\tau(t) \bar{W}}{(1-\bar{p})^{2}}\left(\frac{\bar{p}}{1-\bar{p}} \tau(t) \bar{W}+A\right)^{-(a+1)} \bar{W} \bar{p} \frac{\partial \tau(t)}{\partial t}
\end{aligned}
$$

Remember the budget constraint $b=\frac{\bar{p}}{1-\bar{p}} \tau(t) \bar{W}$ :

$$
\frac{\partial g}{\partial \bar{p}}=\bar{W} \frac{1}{((1-t) \bar{W}+A)^{a}} \frac{\partial \tau(t)}{\partial t} \frac{1}{(b+A)^{a}}\left(1-\frac{a}{1-\bar{p}} \frac{\bar{W} b}{(b+A)}\right)
$$

This expression is negative when $A<\frac{a \bar{W} b}{(1-\bar{p})}-b$, which can teach us several things about how workers react when they face higher labor-market risks. For instance, if workers are risk-averse $a>1$, then they will demand more social insurance when they feel less secure and thus are ready to pay higher taxes in order to spread their risks. Furthermore, increasing returns on asset wealth will weaken this relationship, through an insurance effect. This means the expression becomes smaller as the asset returns grow in size, given that they can be used to maintain consumption during periods of financial constraint. This result resembles the conclusion in Ansell (2014). However, the marginal effect on tax preferences of changes in the risk of unemployment approaches zero as $A \Rightarrow \infty$. This means that unemployment benefits and income taxation are as less important issues for the truly wealthy.

General unemployment, asset returns, and the demand for social insurance. The next step is to investigate how changes in the unemployment rate affect preferences for the tax rate when the general employment rate is independent of the risk of unemployment for the individual worker, so that $p \neq \bar{p}$. As before we find:

$$
\begin{aligned}
\frac{\partial g}{\partial \bar{p}}=- & a(1-p) \frac{\bar{W} \tau(t)}{(1-\bar{p})^{2}}\left(\frac{\bar{p}}{1-\bar{p}} \tau(t) \bar{W}+A\right)^{-(1+a)} \frac{\bar{W} \bar{p}}{1-\bar{p}} \frac{\partial \tau t}{\partial t} \\
& +\frac{1-p}{(1-\bar{p})^{2}} \bar{W} \frac{\partial \tau}{\partial t}\left(\frac{\bar{p}}{1-\bar{p}} \tau(t) \bar{W}+A\right)^{-a}
\end{aligned}
$$

Remember the budget constraint $b=\frac{\bar{p}}{1-\bar{p}} \tau(t) \bar{W}$ :

$$
\frac{\partial g}{\partial \bar{p}}=\bar{W} \frac{(1-p)}{(1-\bar{p})^{2}} \frac{\partial \tau}{\partial t} \frac{1}{(b+A)^{a}}\left[1-\frac{a b}{b+A}\right]
$$

Assuming that $A=0$ for a moment, this expression will be negative as long as workers strive to avoid risks $a>1$. As Markussen (2008) notes, a rise in the employment rate will have two effects on the preferred level of taxation. First, increasing rates of employment will have a positive impact on the demand for social insurance, as the price of this particular good falls. This occurs because fewer workers come to depend on unemployment benefits, and tax revenues increase as more workers enter the labor market. This is the substitution effect. At the same time, however, workers will demand less social insurance, as the benefit is shared among fewer people. In other words, the level of the insurance can be sustained at a lower tax rate. This is the income effect. Markussen 
(2008)) argues that the income effect will dominate the substitution effect if workers are relatively risk-averse $a>1$, which is why the demand for unemployment benefits increases during recessions.

However, this expression becomes positive if $A>(a-1) b$. This means that voters want to replace a more expensive system of social insurance with other goods when asset returns constitute a larger share of their disposable income in the bad state of nature. This effect is observed first among workers who are less risk-averse. Workers who dislike risk must have a greater stream of income from their assets in order to change their behaviour. In other words, the well-off are less dependent on spreading risks and so are more sensitive to changes in the insurance premium. Furthermore, it is clear in this scenario as well that the marginal effect on tax preferences of a change in the employment rate approaches zero as $A \Rightarrow \infty$, indicating the presence of a strong salience effect as well.

These results indicate that asset-poor workers are more likely to demand more social insurance as the unemployment rate rises. Well-off workers, on the other hand, demand less social insurance, as they can use their asset returns as a substitute for it. Furthermore, under the assumption that policy-makers are policy-motivated and that political conflict take a unidimensional form where the left prefers more taxation than the right, voters will sort themselves on the left/right dimension during elections. This means that the left can gain an electoral advantage when the unemployment rate rises, but that this advantage decreases or even becomes negative as voters become wealthier.

\section{Appendix 2: Summary Statistics}

See Tables 2 and 3.

Table 2 Summary statistics

\begin{tabular}{lrrrrr}
\hline & Mean & SD & Min & Max & Count \\
\hline Stock based wealth per voter & 1.05 & 11.12 & 0.00 & 707.73 & 17,868 \\
House based wealth per voter & 2.53 & 2.39 & 0.01 & 22.39 & 17,868 \\
Mutual fund based wealth per voter & 0.75 & 0.32 & 0.01 & 2.97 & 17,868 \\
Apartment based wealth per voter & 0.46 & 1.30 & 0.00 & 14.97 & 17,868 \\
Debt per voter & 2.01 & 1.16 & 0.05 & 14.83 & 17,868 \\
Total wealth per voter & 3.48 & 2.60 & -0.11 & 23.30 & 17,868 \\
Voters & 1248.93 & 338.11 & 121.00 & 2809.00 & 17,896 \\
LWA & 3.14 & 28.64 & -98.09 & 91.67 & 17,896 \\
Left-wing bloc & 47.74 & 14.32 & 0.64 & 95.29 & 17,896 \\
Migrants & 0.14 & 0.12 & 0.00 & 0.95 & 17,896 \\
Education & 11.48 & 0.90 & 9.33 & 15.16 & 17,896 \\
Non-employment & 40.02 & 8.98 & 10.38 & 86.00 & 17,896 \\
Age & 49.69 & 3.98 & 23.58 & 66.13 & 17,896 \\
\hline
\end{tabular}

Wealth and debt expressed as hundred thousands of SEK 
Table 3 Summary statistics discarded districts

\begin{tabular}{lrrrrr}
\hline & Mean & \multicolumn{1}{c}{ SD } & Min & Max & Count \\
\hline Stock based wealth per voter & 0.59 & 0.72 & 0.01 & 6.17 & 2197 \\
House based wealth per vote & 2.35 & 2.06 & 0.02 & 13.91 & 2197 \\
Mutual fund based wealth per voter & 0.72 & 0.33 & 0.04 & 2.19 & 2197 \\
Apartment based wealth per voter & 0.33 & 0.76 & 0.00 & 6.25 & 2197 \\
Debt per voter & 1.90 & 1.01 & 0.22 & 8.29 & 2197 \\
Total wealth per voter & 3.10 & 2.07 & -0.02 & 13.84 & 2197 \\
Voters & 984.25 & 546.78 & 0.00 & 2330.00 & 4996 \\
LWA & 2.21 & 30.39 & -92.67 & 86.07 & 4996 \\
Left-wing bloc vote share & 46.92 & 14.95 & 2.68 & 92.11 & 4996 \\
Migrants & 0.16 & 0.14 & 0.01 & 0.87 & 4288 \\
Education & 11.70 & 1.11 & 8.92 & 15.01 & 4288 \\
Non-employment & 40.08 & 10.31 & 5.36 & 83.29 & 4288 \\
Age & 48.50 & 4.76 & 24.11 & 66.31 & 4288 \\
\hline
\end{tabular}

Wealth and debt expressed as hundred thousands of SEK

\section{Appendix 3: First Stage}

See Table 4.

Table 4 First stage estimates

\begin{tabular}{|c|c|c|c|c|c|}
\hline & 1 & 2 & 3 & 4 & 5 \\
\hline Housing returns $_{d t}$ & $\begin{array}{l}1.279 * * * \\
(0.0501)\end{array}$ & & & & \\
\hline Apartment returns $_{d t}$ & & $\begin{array}{l}0.452 * * * \\
(0.0263)\end{array}$ & & & \\
\hline Mutualfund returns $_{d t}$ & & & $\begin{array}{l}0.480 * * * \\
(0.0468)\end{array}$ & & \\
\hline Stock returns $_{d t}$ & & & & $\begin{array}{l}-0.179 \\
(0.115)\end{array}$ & \\
\hline${ }_{\text {Net Asset returns }} d t$ & & & & & $\begin{array}{l}0.609 * * * \\
(0.0304)\end{array}$ \\
\hline Constant & $\begin{array}{l}-0.381 * * * \\
(0.131)\end{array}$ & $\begin{array}{l}-0.0317 \\
(0.0576)\end{array}$ & $\begin{array}{l}-0.207 * * * \\
(0.0108)\end{array}$ & $\begin{array}{l}-0.814 * * * \\
(0.259)\end{array}$ & $\begin{array}{l}0.535 * * * \\
(0.1000)\end{array}$ \\
\hline$N$ & 8934 & 8934 & 8934 & 8934 & 8934 \\
\hline $\begin{array}{l}\text { Economic and demo- } \\
\text { graphic controls }\end{array}$ & Yes & Yes & Yes & Yes & Yes \\
\hline Year effets & No & No & No & No & No \\
\hline
\end{tabular}

Standard errors clustered on the district level within in parentheses

$* p<.10, * * p<.05, * * * p<.01$ 


\section{Appendix 4: Right-Wing Parties}

See Figs. 5 and 6.

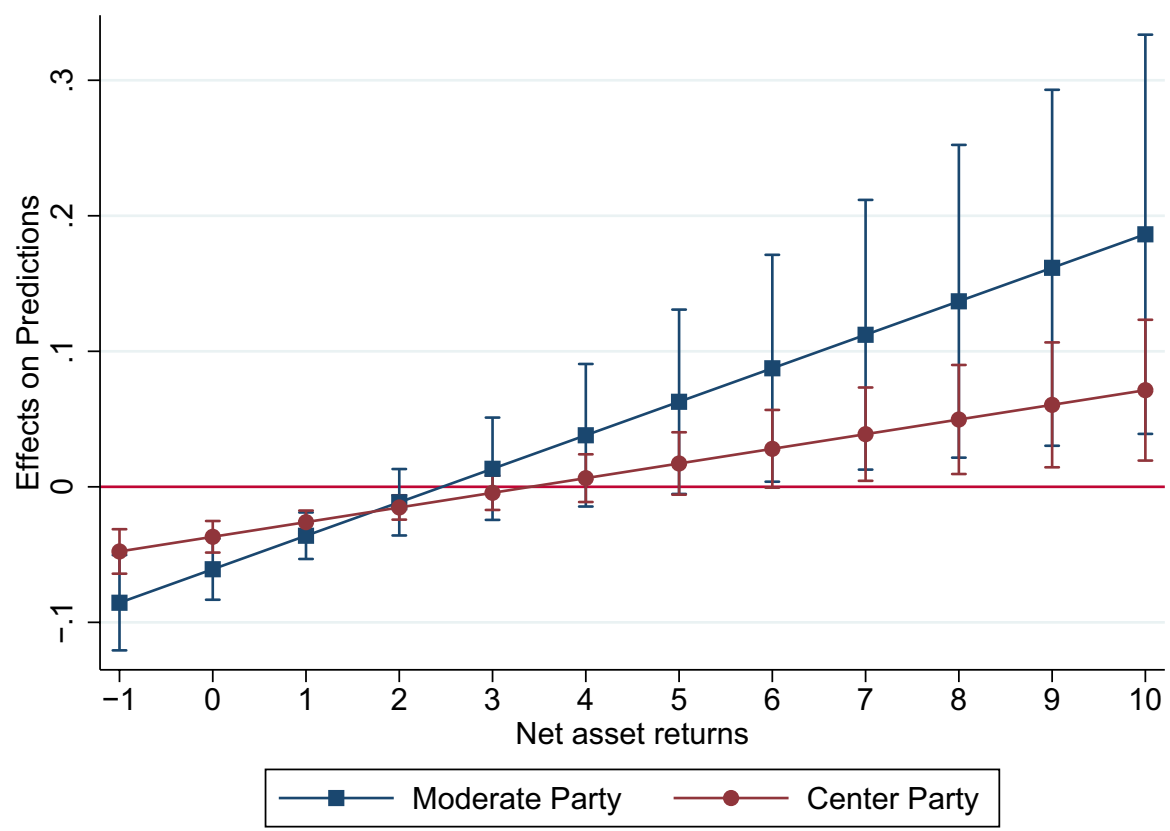

Fig. 5 The effect from growth in non-employment on changes in support for the individual rightwing parties conditional on net asset returns with $95 \%$ confidence level intervals. Net asset returns are expressed as hundred thousands of SEK 


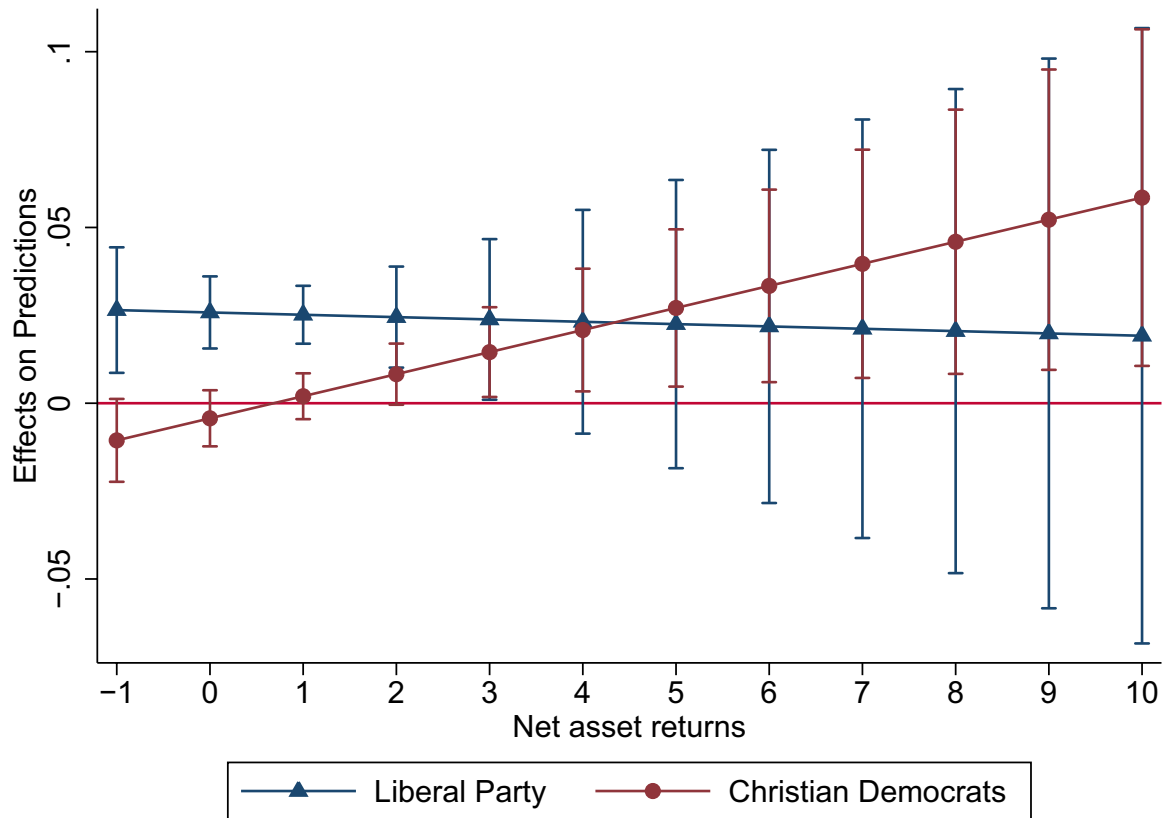

Fig. 6 The effect from growth in non-employment on changes in support for the individual rightwing parties conditional on net asset returns with $95 \%$ confidence level intervals. Net asset returns are expressed as hundred thousands of SEK 


\section{Appendix 5: Bin-Model and Left-Wing Advantage}

See Fig. 7.

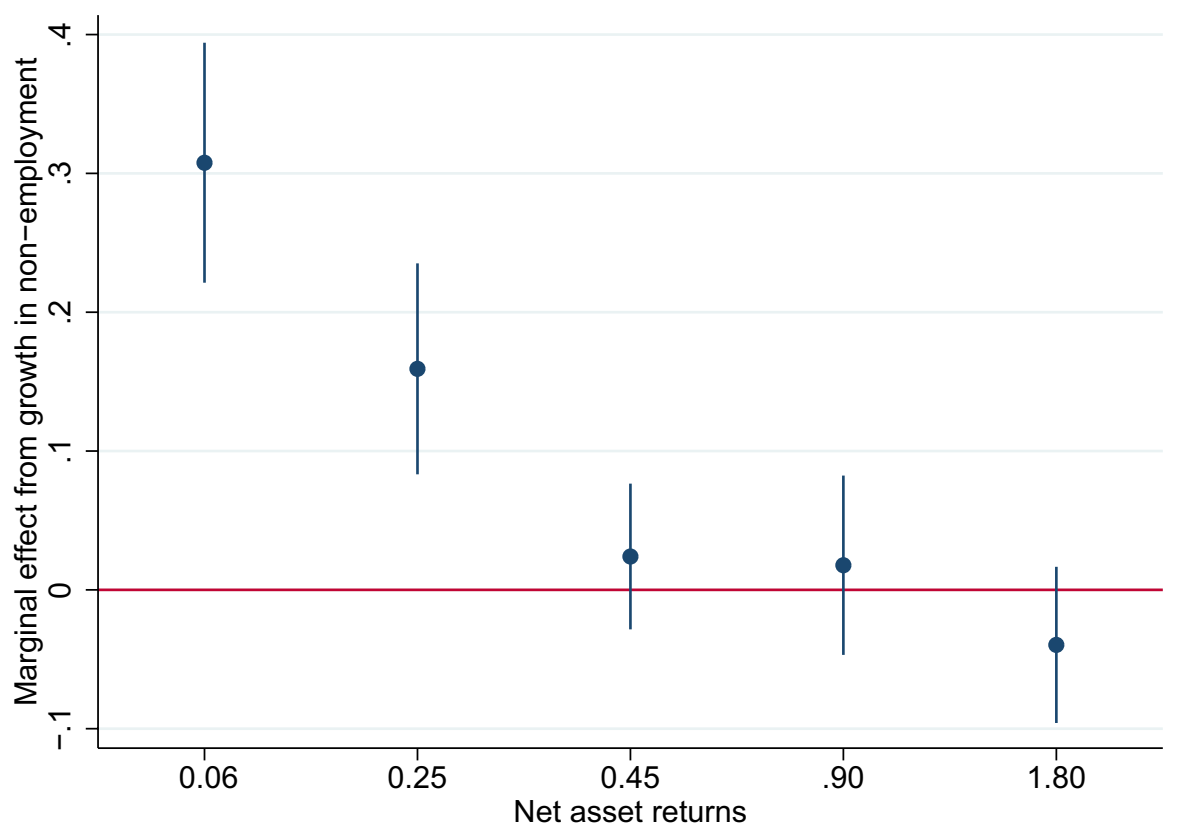

Fig. 7 The marginal effect from growth in non-employment conditional on net asset returns, estimated with a bin-model 


\section{Appendix 6: Goverment Support}

See Fig. 8.

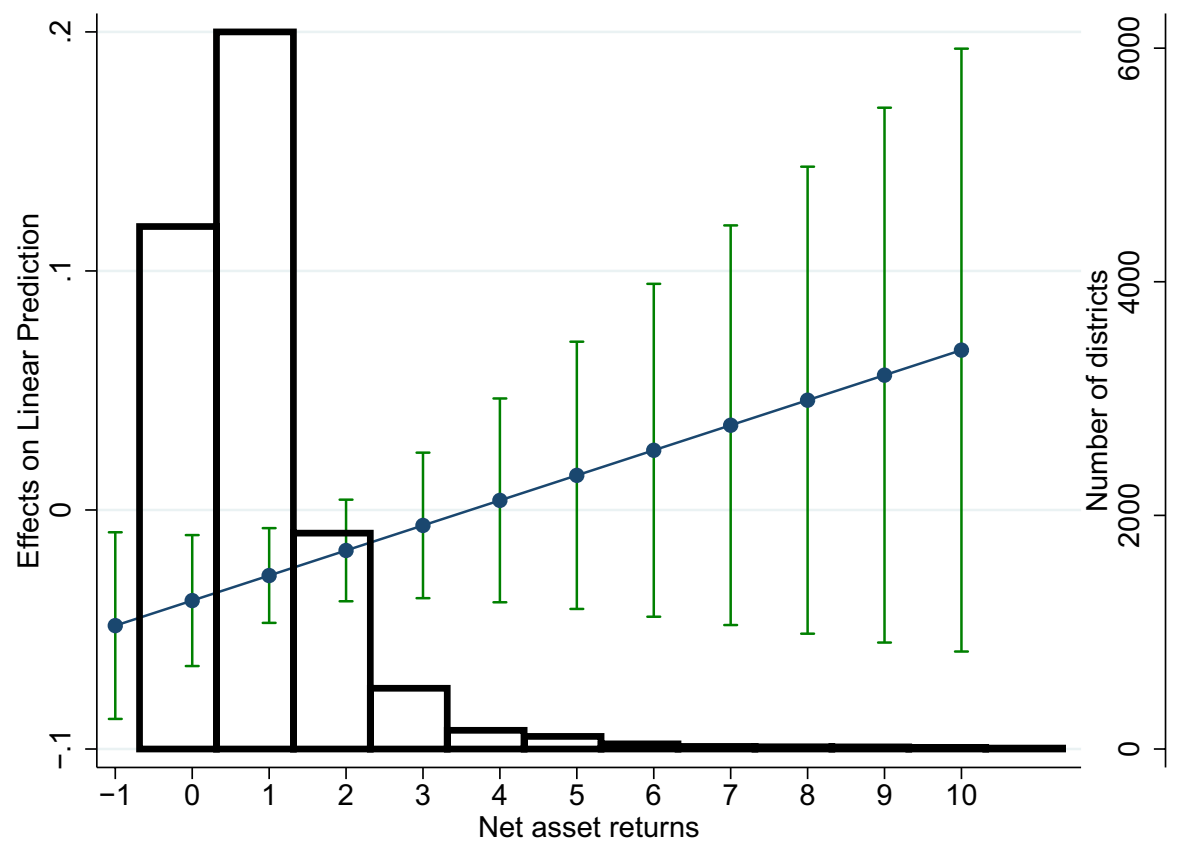

Fig. 8 The effect from growth in non-employment on changes in support for the goverment parties conditional on net asset returns with $95 \%$ confidence level intervals. Net asset returns are expressed as hundred thousands of SEK

\section{Appendix 7: Larger Sample 2002-2014}

In this section, I test for the possibility that my results are driven by sample selection, given that I discard districts that do not remain throughout the whole period 2002 to 2014 . This test is done by re-estimating the model on a larger sample i.e., a sample that includes all districts that remain for at least three periods, which is necessary to estimate the district fixed effects. The results are visible in Table 5. As before, column one presents the simpler relationship between the share of non-employed individuals and the advantage for the left-wing bloc in levels. Column two shows the relationship between growth in non-employment and changes in the left-wing advantage, controlling for the municipality by year fixed effects. I add district fixed effects in column three, and finally, column four presents the full specification with the complete interaction term. 
Table 5 Non-employment, asset returns and the left-wing advantage in the larger sample

\begin{tabular}{lllll}
\hline & 1 & 2 & 3 & 4 \\
\hline Share of workers not employed & $1.451^{* * *}$ & & \\
Non-employment growth & $(0.0305)$ & & & \\
& & $0.292^{* * *}$ & $0.0675^{* * *}$ & $0.133^{* * *}$ \\
Net asset returns & & $(0.0229)$ & $(0.0172)$ & $(0.0227)$ \\
& & & $-0.46^{* *}$ \\
Non-employment growth $\times$ net asset returns & & & $(0.013)$ \\
Constant & & & $-0.0749^{* * *}$ \\
& $-54.85^{* * * *}$ & $-1.215^{* * *}$ & $2.204 * * *$ & $2.617^{* * *}$ \\
N & $(1.235)$ & $(0.00468)$ & $(0.255)$ & $(0.350)$ \\
Year by municipality effects & 23264 & 14846 & 14846 & 14372 \\
Controls & No & Yes & Yes & Yes \\
Controls interacted with wealth & No & No & Yes & Yes \\
Districts effects & No & No & No & Yes \\
\hline
\end{tabular}

Standard errors in parentheses

$* p<.10, * * p<.05, * * * p<.01$

As we can see, this test includes roughly 1000 more observations, but the estimates do not differ much from the main results. This outcome suggests that sample selection does not drive the main result in any significant way.

\section{Appendix 8: Municipality Sample}

I will, in this section, run some additional tests over a longer period, at the higher municipality level to investigate the possible presence of sample selection bias in the main results. However, since there is a lack of wealth data over longer periods, I must use a slightly different approach to capture the impact of asset returns. I define a house-based proxy "housing returns per voter" or $\left(H R P V_{m t}\right)$ as follows:

$$
\begin{aligned}
H R P V_{m t}= & \frac{\text { Number of houses }_{m t} \times \text { Average house price }_{m t}}{\text { Voters }_{m t}} \\
& -\frac{\text { Number of houses } s_{m t-1} \times \text { Average house price }_{m t-1}}{\text { Voters }_{m t-1}}
\end{aligned}
$$

where $m$ stands for municipality and $t$ time period. The $H R P V_{m t}$ will increase more rapidly in areas with more houses compared to voters when house prices appreciate. Equally true: the $H R P V_{m t}$ will decrease more rapidly in areas with more houses compared to voters when house prices depreciate. We can use this to estimate: 


$$
\begin{aligned}
\Delta L W A_{m t}= & \beta_{1} \times N E \text { growth }_{m t}+\beta_{2} \times H R P V_{m t}+\beta_{3} \times N E \text { growth }_{m t} \times H R P V_{m t} \\
& +\beta_{4} \times \Delta X_{m t}^{\prime}+\beta_{5} \times \Delta X_{m t}^{\prime} \times H R P V_{m t}+\zeta_{t}+\delta_{m}+\varepsilon_{m t} .
\end{aligned}
$$

In this specification, $L W A_{i t}$ represents the left-wing advantage at the municipality level during time $t$ expressed here in changes. Where $t=(1988,1991,1994,1998,2002,2006,2010,2014)$. The main independent variables are growth in non-employment NEgrowth $_{m t}$ and returns in housing $H R P V_{m t}$. Adding year-fixed effects $\zeta_{t}$ allow me to cancel out all events that affect all municipalities equally between elections such as swings in the Swedish businesses cycle. $\delta_{m}$ represents a municipality specific fixed effect that control for long-run trends in voting. The vector $X_{m t}^{\prime}$ controls for time-variant confounders, I include changes in demographic and labor market characteristics. The results are presented below.

Table 6 illustrates the impact of growth in the non-employment rate in the municipality sample from 1988 to 2014 . More specifically, the interaction term between growth in non-employment is found in column 4 and is negative and significant. One can also note that this interaction term is much stronger compared to the estimate obtained from the district sample. The conditional effect is visualized in Fig. 9.

Table 6 Non-employment, housing returns and the left-wing advantage in the municipality sample

\begin{tabular}{lllll}
\hline & 1 & 2 & 3 & 4 \\
\hline Non-employment growth & $0.465^{* * *}$ & -0.0384 & $0.100^{* * *}$ & $0.0574 *$ \\
& $(0.0143)$ & $(0.0268)$ & $(0.0282)$ & $(0.0337)$ \\
Housing returns & & & -0.0601 \\
& & & $(0.685)$ \\
Non-employment growth $\times$ housing returns & & & $-0.172^{* * *}$ \\
Constant & & & $(0.0250)$ \\
& $-0.304^{* * *}$ & $6.967 * * *$ & $5.625^{* * *}$ & $4.306^{* * *}$ \\
Year effects & $(0.103)$ & $(0.192)$ & $(0.593)$ & $(1.141)$ \\
Controls & No & Yes & Yes & Yes \\
Fixed effects & No & No & Yes & Yes \\
Controls interacted with net asset returns & No & No & No & Yes \\
\hline
\end{tabular}

Standard errors clustered at the municipality level in parentheses

$* p<.10, * * p<.05, * * * p<.01$ 


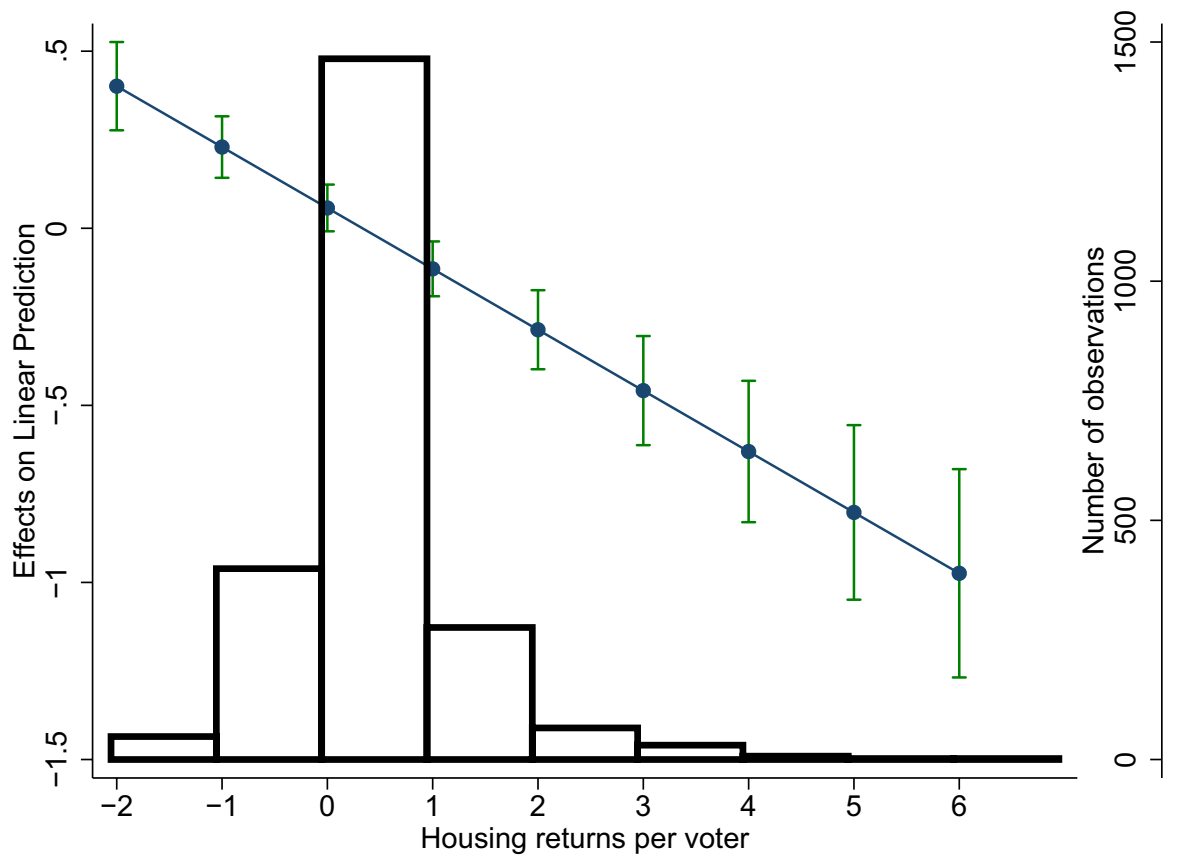

Fig. 9 The effect from growth in non-employment on changes in left-wing advantage conditional on housing returns per voter with $95 \%$ confidence level intervals. Housing returns per voter are expressed as hundred of thousands of SEK

\section{Appendix 9: Separate Elections}

The question asked in the section is if the moderating effect from asset returns on the relationship between growth in non-employment and voting is different during the individual election years. One could suspect that the effect would manifest itself differently in different political and economic contexts. For instance, there was more variation in both non-employment and asset returns in the election after 2006 due to the financial crisis and the great recession. Moreover, there have also been different parties in power in that a left-wing government held office in 2006 while the rightwing parties ruled in the later period. To investigate this possibility, I run similar models to those found in the main results on separate election years. However, a major difference is that these models do not include controls for trends in voting, as this requires that $t \geq 3$. The results from these test are found in Table 7 .

Column one presents the results from a regression on the full period, but without controls for trends in voting to make the result more comparable to the separate elections. The coefficient is similar to the main estimate since it has the right sign and remains significant, but is however, smaller in size. Column 2 to 4 present the results from the individual election years 2006, 2010, and 2014. As we can see, the coefficient for the interaction term seems to grow in size, from - 0.0155 in 2006 to -0.0447 in 2014. This result suggests that the effect can be conditional on the economic and 
Table 7 Non-employment, asset returns and the left-wing advantage during the separate election

\begin{tabular}{lllll}
\hline & 1 & 2 & 3 & 4 \\
\hline Non-employment growth & $0.150^{* * *}$ & $-0.0485^{*}$ & 0.0379 & $0.148^{* * *}$ \\
& $(0.0227)$ & $(0.0292)$ & $(0.0345)$ & $(0.0365)$ \\
Net asset returns & $-0.509 * *$ & $0.322^{* *}$ & $-1.801 * * *$ & $1.942^{* * *}$ \\
& $(0.209)$ & $(0.152)$ & $(0.422)$ & $(0.652)$ \\
Non-employment growth $\times$ net asset returns & $-0.046^{* * *}$ & -0.0155 & -0.0273 & -0.0447 \\
& $(0.0075)$ & $(0.0122)$ & $(0.0414)$ & $(0.0456)$ \\
Constant & $2.941^{* * *}$ & $-7.067 * * *$ & $0.868 * *$ & $12.41 * * *$ \\
& $(0.347)$ & $(0.467)$ & $(0.428)$ & $(0.589)$ \\
N & 13926 & 4642 & 4642 & 4642 \\
Election & All & 2006 & 2010 & 2014 \\
Controls & Yes & Yes & Yes & Yes \\
Controls interacted with net asset returns & Yes & Yes & Yes & Yes \\
Municipality fixed effects & Yes & Yes & Yes & Yes \\
\hline
\end{tabular}

Standard errors clustered at the district level in parentheses.

$* p<.10, * * p<.05, * * * p<.01$

Table 8 Comparing coefficients from individual election years

\begin{tabular}{llll}
\hline & $\beta_{2006}$ & $\beta_{2010}$ & $\beta_{2014}$ \\
\hline$\beta_{2006}$ & $\mathrm{X}$ & 0.70 & 0.46 \\
$\beta_{2010}$ & 0.70 & $\mathrm{X}$ & 0.77 \\
$\beta_{2014}$ & 0.46 & 0.77 & $\mathrm{X}$ \\
\hline
\end{tabular}

P-values from comparing regression coefficients

$* p<.10, * * p<.05, * * * p<.01$

political context. However, to investigate this more thoroughly, I also check if these differences are significant in Table 8.

The first row in Table 8 presents the p-value from the significance test of the difference between the coefficient obtained in the 2006 election and the coefficient estimated in 2010 (column 2), between 2006 and 2014 in column 3. The second and the third row present the same test for the estimates obtained in 2010 and 2014. The results indicate that the estimates are similar in size but that there is much of uncertainty given that loss of precision.

\section{Appendix 10: Using Actual Unemployment Rates and Growth in Unemployment}

In this section I investigate the result when I substitute the main independent variable (relative changes in non-employment) with actual relative changes in unemployment 
Table 9 Unemployment, asset returns and the left-wing advantage

\begin{tabular}{lllll}
\hline & 1 & 2 & 3 & 4 \\
\hline Share of unemployed & $4.73^{* * *}$ & & & \\
& $(0.08)$ & & & \\
Unemployment growth & & $0.145^{* * *}$ & $0.0266^{* * *}$ & $\begin{array}{l}0.0448^{* * *} \\
\text { Net asset returns }\end{array}$ \\
& & $(0.0123)$ & $(0.00589)$ & $(0.00717)$ \\
& & & 0.95 \\
Unemployment growth $\times$ Net asset returns & & & $(1.02)$ \\
& & & & $-0.0158^{* * *}$ \\
Constant & $-39.32^{* * * *}$ & $-0.378^{* * * *}$ & $2.444^{* * *}$ & $(0.00324)$ \\
& $(0.639)$ & $(0.0695)$ & $(0.252)$ & $\left(0.3464^{* * *}\right.$ \\
N & 18976 & 14226 & 14226 & 13926 \\
Year by municipality effects & No & Yes & Yes & Yes \\
Controls & No & No & Yes & Yes \\
Controls interacted with net asset returns & No & No & No & Yes \\
Districts effects & No & No & No & Yes \\
\hline
\end{tabular}

Standard errors in parentheses

$* p<.10,{ }^{* *} p<.05, * * * p<.01$

as these two concepts are not necessarily the same thing. As before, column one illustrates the bivariate relationship between unemployment rates in levels and the left-wing advantage. Column four in Table 9 presents the full specification and the interaction term between growth in the unemployment rate and net asset returns. The estimate has the same sign as in the main results and is significant but is, however, smaller in size.

This difference can arise since the unemployment rate is much lower than the non-employment rate in general, which in turn can increase the size of the relative changes in unemployment-the average relative change in the non-employment rate where -0.22 with a standard deviation of 10 . The average relative change in the unemployment rate was on the other hand -5 with a standard deviation of 25 .

\section{Appendix 11: Exploring the Interaction Term at the Individual Level}

In this section, I turn to survey data as this allows me to investigate the interaction term between net asset returns and the risk of unemployment at the individual level. This exercise is important because a higher-level analysis can only tell which political bloc that benefit from wealth at the aggregated level when the labor market is weak. The problem, more commonly known as the "ecological fallacy", states that one cannot draw inferences about individuals based on group-level correlations. Data over voting comes from the Swedish SALTY survey, this survey was done to investigate inheritance, health, and behavior among Swedish twins. Some of the question were of a political nature, and allow me to see how the respondents voted 
Table 10 Risk of unemployment, change in wealth and left-wing voting

\begin{tabular}{llll}
\hline & $(1)$ & $(2)$ & $(3)$ \\
\hline Change in net wealth & -0.00366 & $-0.0150^{* *}$ & $-0.0128^{*}$ \\
& $(0.00237)$ & $(0.00675)$ & $(0.00730)$ \\
Risk of unemployment & $1.031^{* * *}$ & 0.227 & 0.594 \\
& $(0.104)$ & $(0.432)$ & $(0.528)$ \\
Change in net wealth & $-0.0506^{* * *}$ & $-0.0386^{* *}$ & $-0.0395^{* *}$ \\
$\times$ Risk of unemploy- & & & \\
ment & & & \\
& $(0.0160)$ & $(0.0185)$ & $(0.0187)$ \\
Constant & $0.391^{* * *}$ & $0.742^{* * *}$ & $0.630^{* * *}$ \\
& $(0.0180)$ & $(0.0787)$ & $(0.0968)$ \\
Observations & 7,646 & 7,646 & 7,646 \\
Years of education & No & Yes & Yes \\
Age fixed effects & No & No & Yes \\
\hline
\end{tabular}

Standard errors in parentheses

$* * * \mathrm{p}<0.01, * * \mathrm{p}<0.05, * \mathrm{p}<0.1$

during the 2006 general election. I connect these survey answers to register data on net wealth, occupational unemployment rates and a group of control variables. Consider the following specification:

$$
\begin{aligned}
\text { Left }_{i}= & \alpha+\beta_{1} \times \text { Risk of unemployment } \\
& +\beta_{2} \times \Delta \text { Net } \text { wealth }_{i}+\beta_{3} \times X_{i}^{\prime} \\
& +\beta_{4} \times \text { Risk of unemployment }{ }_{i} \times \Delta \text { Net } \text { wealth }_{i} \\
& +\beta_{5} \times X_{i}^{\prime} \times \text { Risk of unemployment }{ }_{i}+\beta_{6} \times X_{i}^{\prime} \times \Delta \text { Net } \text { wealt }_{i}+\varepsilon_{i}
\end{aligned}
$$

In Eq. (24), the term Left $t_{i}$ is a dummy variable which takes the value 1 if a voter voted for the left-wing bloc in the 2006 general election in Sweden and 0 otherwise. The Risk of Unemployment ${ }_{i}$ represents the occupational unemployment rate. A higher occupational unemployment rate implies a higher risk of unemployment and, thus, greater economic insecurity. It is also possible to interpret this variable as a social class indicator given that high-income groups have, in general, lower occu-

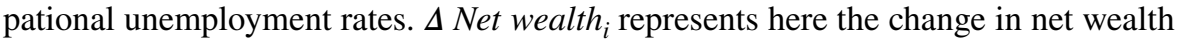
at the individual level between 2002 and 2006 and is measured in 100,000 of SEK.

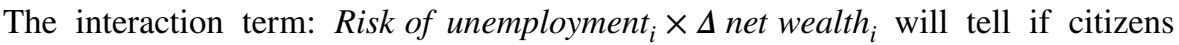
who face a similar risk of unemployment or belong to the same social class become less likely to vote for a left-wing party when they grow wealthier. Finally, to make the specification more correct, I also add control variables at the individual level, such as age, years of education, and age fixed effects. To allow for a heterogeneous impact from these controls, I generate an interaction term between vector $\mathrm{X}$ and both the risk of unemployment and changes in net wealth. The result can be seen in Table 10. 
In column one, I test these relationships without adding any additional control variables, and as we can see, the estimates resemble the main finding. More in detail, higher occupational unemployment rates are related to an increased probability of voting on a left-wing party, but this relationship is mitigated by increases in net wealth, given that the interaction term is positive and significant. Furthermore, the interaction term increases in size after adding both years of education in column 2 and age fixed effects in column 3. In sum, these findings lend some support to the main results in that wealth seems to mitigate the impact of risk of unemployment on left-wing voting.

\section{References}

Anderson, C. D., \& Roy, J. (2011). Local economies and national economic evaluations. Electoral Studies, 30(4), 795-803.

Ansell, B. (2014). The political economy of ownership: Housing markets and the welfare state. American Political Science Review, 108(2), 383-402.

Ansolabehere, S., Meredith, M., \& Snowberg, E. (2014). Mecro-economic voting: Local information and micro-perceptions of the macro-economy. Economics and Politics, 26(3), 380-410.

Bandau, F. (2017). The impact of partisanship in the era of retrenchment: Insights from quantitative welfare state research. SSRN Electronic Journal

Bartels, L. M. (2002). Beyond the running tally: Partisan bias in political perceptions. Political Behavior, 24(2), 117-150.

Bisgaard, M., Dinesen, P. T., \& Sønderskov, K. M. (2016). Reconsidering the neighborhood effect: Does exposure to residential unemployment influence voters' perceptions of the national economy? The Journal of Politics, 78(3), 719-732.

Chetty, R. (2008). Moral hazard versus liquidity and optimal unemployment insurance. Journal of Political Economy, 2(116), 173-234.

Chong, D., Citrin, J., \& Conley, P. (2001). When self-interest matters. Political Psychology, 22(3), 541-570.

Cusack, T., Iversen, T., \& Rehm, P. (2006). Risks at work: The demand and supply sides of government redistribution. Oxford Review Economic Policy, 3(22), 365-389.

Dassonneville, R., \& Lewis-Beck, M. S. (2013). Economic policy voting and incumbency: Unemployment in western Europe. Political Science Research and Methods, 1(1), 53-66.

Doling, J., \& Ronald, R. (2010). Home ownership and asset-based welfare. Journal of Housing and the Built Environment, 25(2), 165-173.

Durr, R. H. (1993). What moves policy sentiment? American Poltical Science Review, 87(1), 158-170.

Elinder, M. (2010). Local economies and general elections: The influence of municipal and regional economic conditions on voting in sweden 1985-2002. European Journal of Political Economy, 26(2), 279-292.

Enns, P. K., Kellstedt, P. M., \& McAvoy, G. E. (2012). The consequences of partisanship in economic perceptions. Public Opinion Quarterly, 76(2), 287-310.

Foucault, M., Nadeau, R., \& Lewis-Beck, M. (2013). Patrimonial voting: Refining the measures. Electoral Studies, 32(3), 557-562.

Gerber, A. S., \& Huber, G. A. (2010). Partisanship, political control, and economic assessments. American Journal of Political Science, 54(1), 153-173.

Hainmueller, J., Mummolo, J., \& Xu, Y. (2019). How much should we trust estimates from multiplicative interaction models? Simple tools to improve empirical practice. Political Analysis, 27(2), 163-192.

Hansford, T. G., \& Gomez, B. T. (2015). Reevaluating the sociotropic economic voting hypothesis. The Journal of Politics, 39(1), 15-25.

Iversen, T., \& Soskice, D. (2001). An asset theory of social policy preferences. American Political Science Review, 98, 875-893.

Johnston, R., Sarker, R., Jones, K., Bolster, A., Propper, C., \& Burgess, S. (2005). Egocentric economic voting and changes in party choice: Great britain 1992-2001. Journal of Elections, Public Opinion and Parties, 15, 129-144. 
Kayser, M. A. (2009). Partisan waves: International business cycles and electoral choice. American Journal of Political Science, 53(4), 950-970.

Kayser, M.A., \& Grafström, C. (2016). The luxury goods vote: Why left governments are punished more for economic downturns.

Kiewiet, D. R., \& Lewis-Beck, M. S. (2011). No man is an island: Self-interest, the public interest, and sociotropic voting. Critical Review, 23(3), 303-319.

Knotz C (2018) Why countries 'get tough on the work-shy': The role of adverse economic conditions. Journal of Social Policy, 1-20.

Ladner, M., \& Wlezien, C. (2007). Partisan preferences, electoral prospects, and economic expectations. Comparative Political Studies, 40(5), 571-596.

Lewis-Beck, M., Nadeau, R., \& Foucault, M. (2013). The compleat economic voter: New theory and british evidence. British Journal of Political Science, 43(2), 241-261.

Lewis-Beck, M. S., \& Paldam, M. (2000). Economic voting: An introduction. Electoral Studies, 19(2), $113-121$.

Lindgren, K., \& Vernby, K. (2016). The electoral impact of the finacial crisis: Evidence using districtlevel data. Electoral Studies, 44(1), 214-224.

Lindvall, J. (2017). Economic downturns and political competition since the 1870s. The Journal of Politics, 79(4), 1302-1314.

Lindvall, J., Martinsson, J., \& Oscarsson, H. (2013). Party choice in hard times: Group-specific responses to economic downturns in sweden. Electoral Studies, 32(3), 529-535.

Margalit, Y. (2013). Explaining social policy preferences: Evidence from the great recession. American Political Science Review, 107(1), 80-103.

Markussen, S. (2008). How the left prospers from prosperity. European Journal of Political Economy, 24(2), 329-342.

Moene, K. O., \& Wallerstein, M. (2001). Inequality, social insurance, and redistribution. American Political Science Review, 95(4), 859-874.

Neve, J. E. D. (2014). Ideological change and the economics of voting behavior in the US, 1920-2008. Electoral Studies, 34, 27-38.

Osberg, L. (1998). Economic insecurity. SPRC Discussion Paper 88, Social Policy Research Centre.

Park, T., \& Reeves, A. (2018). Local unemployment and voting for president: Uncovering causal mechanisms. Political Behavior.

Persson, M., \& Martinsson, J. (2018). Patrimonial economic voting and asset value-New evidence from taxation register data. British Journal of Political Science, 48(3), 825-842.

Powell, G. B., \& Whitten, G. D. (1993). A cross-national analysis of economic voting: Taking account of the political context. American Journal of Political Science, 37(2), 391-414.

Ramirez, M. D., \& Erickson, N. (2013). Partisan bias and information discounting in economic judgments. Political Psychology, 35(3), 401-415.

Reeves, A., \& Gimpel, J. G. (2012). Ecologies of unease: Geographic context and national economic evaluations. Political Behavior, 34(3), 507-534.

Rehm, P. (2009). Risks and redistribution: An individual-level analysis. Comparative Political Studiess, 42(7), 855-881.

Rehm, P. (2011). Social policy by popular demand. World Politics, 63(2), 271-299.

Rehm, P. (2012). Insecure alliances: Risk, inequality, and support for the welfare state. The American Political Science Review, 106(2), 386-406.

Ronald, R., Lennartz, C., \& Kadi, J. (2017). What ever happened to asset-based welfare? Shifting approaches to housing wealth and welfare security. Policy and Politics, 45(2), 173-193.

Simonovits, G., Kates, S., \& Szeitl, B. (2018). Local economic shocks and national election outcomes: Evidence from Hungarian administrative data. Political Behavior.

Stevenson, R. T. (2001). The economy and policy mood: A fundamental dynamic of democratic politics. American Journal of Political Science, 45(3), 620-633.

Whitten, G. D., \& Palmer, H. D. (1999). Cross-national analyses of economic voting. Electoral Studies, $18(1), 49-67$.

Wright, J. R. (2012). Unemployment and the democratic electoral advantage. The American Political Science Review, 106(4), 685-702.

Publisher's Note Springer Nature remains neutral with regard to jurisdictional claims in published maps and institutional affiliations. 